\title{
Using the Local to Tell a Global Story:How the Peabody Essex Museum Became a World Class Museum
}

\author{
Peggy Levitt* Wellesley College/Harvard University \\ Katherine Cali** Wellesley College
}

\begin{abstract}
According to the World Bank, one out of every seven people in the world today is an internal or international, voluntary or involuntary migrant. Learning to live with diversity next door or across the globe is the challenge of the day. What role are contemporary museums playing in imparting cosmopolitan values and skills to their visitors? What helps explain how they present the nation in relation to the world? In this article, we use the case of the Peabody Essex Museum, in Salem, Massachusetts to explore these questions. In 1993, the Peabody Museum and the Essex Institute were poised to close. Despite their long histories and important collections, they were operating at the far frontier of the regional cultural map. In the ensuing years, the new PEM rewrote that cartography. By telling new global stories about very local objects, and by showcasing its global institutional roots, the museum dramatically transformed visitors' experiences. It broadened and diversified the possible messages they might take away from their visits and sought to connect them to other times and places. Excavating pieces of Salem's cultural armature enabled the PEM to display cosmopolitan ideas and to cultivate cosmopolitan skills while rescaling itself and its city in the process.
\end{abstract}

Key words: museums, cosmopolitanism, global, culture, scale

\section{Introduction}

'A Cabinet. That every mariner may possess the history of the world'. A toast offered by a member of the East India Marine Society regarding the Society's museum, 1804 (Lindgren 1995: 184).

'Through its exhibitions, programs, publications, media and related activities, [the Peabody Essex Museum] strives to create experiences that transform people's lives by broadening their perspectives, attitudes, and knowledge of themselves and the wider world'. From Peabody Essex Museum's 'Mission \& Vision Statement,' 2015. ${ }^{1}$

The world is in the throes of a terrible refugee crisis. According to the UNHCR, in 2014 there were almost 60 million refugees and internally displaced people (IDPs). That is approximately one out of every 122 people, or roughly the equivalent of every Italian leaving his or her home. It does not include the large numbers of Syrian refugees who are forced to flee their communities each day (UNIS 2014).

'Forced migration' is not the only category of movement that is on the rise. In 2014, William Swing, Director General of the International Organization For Migration (IOM 2015), stated that in addition to the 214 million international migrants, there are an estimated 740 million internal migrants worldwide. That means that nearly one billion people (or roughly one out of every seven people in the world today) are voluntary or involuntary, internal or international migrants. More and more, they move between countries in the global south rather than from south to north.

Many of these people stay active in their homelands, either by choice or because they have no alternative. They continue to vote, invest in businesses, and participate in civic 
associations in their countries of origin at the same time that they buy homes, open stores, and join community groups in the places where they settle. These dynamics challenge long-standing assumptions about how people live-how and where they raise their families, how class and gender are constituted, and where the rights and responsibilities of citizenship get fulfilled.

A key question raised by this twenty-first century world of heightened mobility is how people learn to feel part of national and global communities at the same time and how these allegiances speak to one another? Since museums, in the past, played such important roles in creating nations and national citizens, are they also helping to create global citizens today? What explains how the nation gets displayed, who is included and where its boundaries are, and how it is positioned in the world? What is it about the city and the nation that helps explain their cultural institutions' choices?

In this article, we examine the case of the Peabody Essex Museum (PEM) in Salem, Massachusetts to explore these questions. The PEM was created in the early 1990 s from the merger of two long-established cultural institutions-one tightly focused on local and regional history and another that showcased its wide-ranging, globally-significant maritime history and associated artifacts. We argue that the PEM reinvented itself, and repositioned itself more prominently in the global cultural hierarchy by (re)connecting to its global roots, and those of the city around it, and by (re)interpreting provincial objects through a global lens. The Museum invites visitors to embrace cosmopolitan values and skills by using the objects in its collections to explore global ideas and experiences, and by encouraging visitors to develop empathy, curiosity, critical thinking, and openness both within and outside the museum. By (re)embracing Salem's cultural armature, and by purposefully showcasing its longstanding global connections, the PEM spreads cosmopolitan ideas and values, and has enhanced its institutional profile and that of the city around it.

\section{Theoretical Debates}

Our project speaks to two literatures: work on cosmopolitanism and global citizenship and work on urban economies and the role of culture in their transformation. Here, we briefly discuss each in turn.

Cosmopolitanism is a term often associated with so much western-centric baggage that many believe it is beyond repair. Others have suggested new formulations to redress these concerns. Paul Gilroy, for example, writes of conviviality (2005). According to Ulf Hannerz (1990), competent cosmopolitans have the ability to make their way 'into other cultures, through listening, looking, intuiting and reflecting.' They have, according to Magdalena Nowicka and Maria Rovisco (2009), 'a mode of self-transformation, which occurs when individuals and groups engage in concrete struggles to protect a common humanity and become more reflective about their experiences with otherness'. Elijah Anderson (2010) wrote about 'cosmopolitan canopies' under which diverse people come together while Nina Glick Schiller, Tsypylma Darieva, and Sandra Gruner-Domic (2011) describe cosmopolitan sociabilities, or the skills and competencies people need to participate openly and inclusively in these spaces.

Hiro Saito's (2011) view of cosmopolitanism includes three parts: cultural omnivorousness, ethnic tolerance, and cosmopolitics. 'Cultural omnivorousness' is the willingness to appreciate a wide variety of cultural objects. Ethnic tolerance consists of having a positive attitude toward ethnic groups other then your own. Cultural omnivorousness and ethnic tolerance, according to Saito, refer to the aesthetic and ethical dimensions of cosmopolitanism, while cosmopolitics captures its political dimension.

For Levitt (2015), cosmopolitanism was an empirical question. She asked the 163 museum professionals she interviewed while writing Artifacts and Allegiances: How Museums Put the Nation and the World on Display, about their definitions and if they saw themselves as creating cosmopolitans through their work. Her conversations also revealed a three-part view. For some people, it was an idea or ethos. For others, it was the skills and practices needed to engage with different people and experiences. For others, it was a political project (cosmopolitics) - what would a cosmopolitan world look like and what we would have to do to create it? Cosmopolitan values and skills generally included things like curiosity, tolerance, empathy, listening, critical thinking, and being open to interactions with different people and 
experiences. Sometimes, things like human rights, democracy, and gender equality were also mentioned but by no means by everyone.

Clearly, some individuals are more able or willing to sign on to creating a more cosmopolitan world than others. Citizenship status, class, and gender are just some of the factors affecting its accessibility and appeal. Nor is the idea of cosmopolitanism to agree on a standardized shopping list of 'universal' values. In fact, rejecting understandings of cosmopolitanism that don't match our own is a distinctly un-cosmopolitan stance. Rather, cosmopolitanism might be best understood as the recognition, willingness, and skill set required to participate in a respectful, constructive conversation about what our common ground might be (Levitt 2015).

The cultural and heritage sectors are often sites where the relationship between nationalism and cosmopolitanism is negotiated. According to Levy and Sznaider (2006), we are transitioning from national to cosmopolitan memory cultures. Institutions such as Holocaust memorials and museums take us beyond collective memories rooted in particular national or ethnic experiences to those framed as belonging to the 'world' or 'humanity,' where all people are reminded to 'never forget.' Despite the broad shifts they chart, cosmopolitan and nationalistic portrayals are nonetheless often deeply intertwined (Macdonald and Daugbjerg 2013). For example, the reinvention of the Danish battlefield Dybbøl, as a monument to peacekeeping rather than conflict, drew upon Danes' perceptions of themselves as a cosmopolitan nation characterized by tolerance and humanitarianism (Daugbjerg 2009). In this case, as in others, the nation 'is still important because of its emotional impact and as a frame of action, although it is difficult 'to "do nation-ness" in quite the same ways in which it was formerly done' (Macdonald 2013: 215).

What might explain where museums fall on this cosmopolitan-nationalism continuum? How might we understand how they put the nation, and its place in the world, on display? One piece of the answer is the cultural armature of the city where a museum is located. By that we mean the deep cultural structures, histories, institutions, and demographies that shape cultural institutions from their foundation and that continue to echo and ripple over time. Traditional ways of thinking and acting mark the city's present-day brick and mortar. Attitudes toward social hierarchy, the responsibility of more affluent members to those less fortunate, or the role of the state in caring for its citizens appear and reappear throughout history. These attitudes and values affect the kinds of institutions a city creates, the policies it embraces, and the values that undergird them: in essence, how it sees itself in relation to the rest of the world.

A second factor which explains where museums fall on the cosmopolitan-nationalism continuum is the city's position within the global cultural hierarchy. To varying degrees, museums operate within transnational social fields-multi-layered, unequal networks created by individuals, institutions, and governance structures. More and more, the things on display, the museum professionals who put them there, the financial and administrative arrangements that make it all possible, and the visitors who enjoy the fruits of these labors are connected to people, objects, and politics all over the world. A city, and its museums, may operate very close to the centers of cultural power, strongly influencing and influenced by them, or they may be located far from their orbit and influences. When cities shift position, they (re) scale themselves, ranking and re-ranking themselves into different, though intersecting, ladders of power (Caglar and Glick Schiller 2011).

The PEM's transformation from an inward-looking museum of local history to an international museum of art and culture, and the subsequent cultural repositioning or rescaling of the city around it, happened, in part, because it reconnected to its own, and Salem's, cosmopolitan roots. Until advances in technology created commercial ships too large for its relatively shallow harbour, Salem's maritime industry flourished in the late eighteenth and early nineteenth centuries. Because the museum's founders' vocations, as sea captains, were international trade and travel, global issues have always been part of the PEM's portfolio. By showcasing this global past, and by telling global stories about the origin, function, or meaning of seemingly local materials, the PEM has propelled itself, and its city, to greater cultural prominence. It remains to be seen, however, whether this cultural rescaling will also produce lasting economic benefits.

This article draws on findings from a larger research project about how museums around the world are responding to immigration and globalization (Levitt 2015). Here we report 
on 23 interviews conducted with administrators and curators at the PEM between 2011 and 2012. We also visited various exhibitions, attended gallery talks and special programs, and did participant observation in the Museum's many spaces. We supplemented these materials with analyses of exhibition catalogues and media accounts.

\section{Setting the Stage}

In 1992, the Boards of the Peabody Museum and the Essex Institute, themselves formed from earlier mergers of local institutions, entered into a marriage of convenience in order to survive. Though beloved by some as, respectively, 'America's great maritime museum' and 'a repository of early American historical artifacts' (McCabe 1999: 7KN1), others recalled these two museums as 'elite and cold' 'old-guard [institutions]' 'that looked more inward than outward'; 'dark, dusty, and stodgy' 'backward-looking colonial [institutions]' (Cook 2012, 2008). Visitors were few, budgets were tight, and, according to several critics, new ideas were unwelcome. Today's Peabody Essex Museum (PEM), sometimes described as the oldest continuing operating museum in the United States due to its venerable precursors, looks almost nothing like the institutions from which it emerged.

The histories of the Peabody Museum and the Essex Institute correspond to that of the city in which they are located. Incorporated twelve miles from Boston in 1629, Salem was once an important centre of international trade-particularly with Asia and the Pacific-and the sixth largest city in Britain's North American colonies. But just as its cultural institutions grew dusty and abandoned, so the city's fortunes also declined. The region's economic base in shipping and manufacturing had collapsed by the twentieth century, along with Salem's political and cultural importance.

Therefore, when Dan Monroe, the Rose-Marie and Eijk van Otterloo Director and CEO of the PEM, announced his goal to 'create a new kind of art museum' that used cutting-edge practices 'to create artistic and culture experiences, ideas, and information that transform people's lives,' many believed he was destined to fail. ${ }^{3}$ But by 2008 , the self-consciously hip Boston Phoenix, then the area's principle alternative weekly paper, was asking its readers, 'Could the Peabody Essex Museum be the Boston area's most exciting art museum right now?' 'Nobody,' noted author Greg Cook (2008) tellingly, 'would have asked [such a question] five or 10 years ago.' By 2012, Cook, by then public radio station WBUR's arts reporter and critic, boasted that the PEM had become 'one of the most thrilling museums in the region and one of the best in the world.'

According to the PEM, since 1993, the Museum 'has increased its operating budget from $\$ 3.4$ million to $\$ 24$ million, its endowment from $\$ 23$ million to more than $\$ 300$ million, direct attendance at the PEM from 80,000 to 250,000 , and visitors to PEM traveling exhibitions from zero (because it had none) to more than half a million.' ${ }^{\prime 4}$ The change is qualitative as well as quantitative. The international art press has seconded the Boston Phoenix's assessment of the new PEM as a 'deeply engaged, internationally attuned, progressive contemporary museum' (Cook 2008). Moreover, the curatorial innovations that PEM Director Monroe instituted have become models that some museums around the world emulate. The museum developed 'a distinctive institutional personality' and successfully balanced sophistication with accessibility: 'a scholarly but often playful mix of old and new, Yankee and international, fine, folk, and decorative art — that throws out traditional aesthetic hierarchies' (Cook 2008).

Visitors and donors have also embraced the new PEM. Now ranked 'among the top 20 art museums in the U.S. by measures including gallery space and endowment' (Dobryzynski 2013), in 2011 the PEM announced that a 'quiet campaign' initiated in 2006 had already raised $\$ 550$ million (out of $\$ 650$ million goal set for 2016). This was the largest ever fundraising campaign by any museum in the state (McCabe 2011, Cook 2012). ${ }^{5}$

How did the PEM accomplish this dramatic transformation in scale and status? How could it go from being a dusty, empty, nearly-forgotten destination to a hub of innovation and interest? We argue that in addition to effective leadership and changes in fundraising strategies, one of the principal engines driving the PEM's dramatic transformation has been its concerted efforts at cultural re-positioning - an active re-framing of the institution, and its position relative to the city, through the savvy reconnection to and deployment of the local cultural armature. 
As one prescient architectural review of the PEM's then-new building noted (designed by global 'starchitect' Moshe Safdie and opened in 2003), the evolution of the PEM represents 'a bid to put the institution... on a number of local, regional, national, and even international maps' (Murphy 2003: 11) —an effort to explicitly connect the museum, and the city where it is located, to the broader social field in which it is embedded and to enhance its position within it.

This analogy works on multiple levels: not only has the PEM become globally respected and influential (i.e. it has taken its place on the international artistic and cultural map), it has done so, in part, by contextualizing its collections within far wider-ranging and more complex maps than those its parent institutions relied upon. The PEM reinvented itself by re-interpreting the unique collections it had amassed because of Salem's distinctive local history through a cosmopolitan lens, using them to communicate broadly defined cosmopolitan values. No longer solely a repository of local heritage, nor of a mere cabinet of wonders, it is a site where the local and global are consciously brought into communion. The strategies the PEM used to redefine itself as globally significant also contributed to the repositioning of Salem as a global cultural destination.

\section{Staking a Global Claim by Reconnecting to the Local}

During Salem's swashbuckling era as the newly independent United States' first centre of international trade and crucial seaport, the Peabody Essex Museum's two parent institutions were founded with complementary objectives. After making their fortunes privateering during the Revolutionary War, Salem's sea captains and merchants strove to achieve a respectability that matched their great wealth. Because the UK continued to block U.S. access to Atlantic trade, even after the war's end, Salem's maritime elite set their sights on the farther but more welcoming shores of China, India, and other parts of Asia. Following the routes of what became known as the Old China Trade, Salem ships returned to the U.S. with highly desirable luxury goods - the products of a flourishing Asian export manufacturing industry-that consumers in the increasingly prosperous and industrializing republic snapped up. ${ }^{6}$

Old China Trade merchants brought back not just consumer goods (such as porcelain, indigo, fabrics, tea, lacquered fans, cinnamon, and furniture) but also unusual objects from East Asia, Africa, India, Oceania, and western North America that often were kept for personal display rather than sold for profit. In 1799, a number of like-minded Salem sea captains established the East India Marine Society. They wrote into their charter a provision to create a 'cabinet of natural and artificial curiosities' that would display souvenirs from members' trip around the world. This cabinet of wonders developed into the more professionalized Peabody Academy of Science and then the Peabody Museum of Salem in the twentieth century.

The East India Marine Society was a membership-only organization; only those who had sailed around either the Cape of Good Hope or Cape Horn and paid a fee were qualified to join. Wealthy ship owners and sea captains contributed the 'curiosities' they collected to stock the Hall's display cases. These men were among a handful of Americans who had experienced non-Western cultures firsthand. In Moby Dick, Herman Melville's depiction of Salem's neighbor New Bedford as a site of cross-cultural contact (both literal and figurative) could also be applied to Salem:

In thoroughfares nigh the docks, any considerable seaport will frequently offer to view the queerest looking non-descripts from foreign parts. Even in Broadway and Chestnut Streets, Mediterranean mariners will sometimes jostle with affrighted ladies. Regent Street is not unknown to Lascars and Malays: and at Bombay, in the Apollo Green, live Yankees have often scared the natives.

PEM Director Dan Monroe believes these Yankee entrepreneurs possessed a 'global perspective. They were more familiar with Canton or Calcutta than they were with Philadelphia or New York.' In his telling, their travels and contacts with people across the world transformed these former colonial subjects into cosmopolitans capable of 'coming on equal terms to do business with people in other cultures'. ${ }^{7}$

Meanwhile, the founders of the nearby Essex Institute (itself formed from the merger of the Essex Historical Society and Essex Natural History Society in 1848) gathered together 
artifacts representing the region's history and natural environment. The Essex Institute and the Peabody Museum developed complementarily and in collaboration, with the Institute giving up its natural history and archaeology collections to the Museum in the 1860s in exchange for the Museum's local history collection. While Salem eminences' global voyages played an important role in the story it told, the Institute was primarily concerned with how these men and their families lived back home. For many years, the Institute was a kind of athenaeum, with a library and only the occasional exhibit. In the late 1800s, the Institute shifted its focus from natural history to local decorative arts and historic houses. It became an early leader in the historic preservation movement by becoming one of the first US institutions to display period rooms.

The region's prominent citizens and gentlemen scholars sustained these two neighboring institutions for more than a century by contributing heavily to their financial support, collections, and research. But by 1992, like Salem, both institutions had been struggling-not least financially - for decades. Leaders felt they would have a better chance of surviving if they merged. In 1993, Dan Monroe was hired as Director of the newly unified institution and charged with planning and implementing what he describes as a 'fundamental remaking' of the museum. ${ }^{8}$

Though the remade Peabody Essex Museum is largely well regarded locally now, initially its transformation attracted considerable skepticism and discontent. Some critics still remain unconvinced. PEM staff typically blame these reservations on people's resistance to change and to a nostalgic attachment to tradition. According to Dan Finemore, the Russell W. Knight Curator of Maritime Art and History, 'Museums are storehouses of tradition, people don't like to see them modified... If someone came into the museum with their grandfather in 1948 , they wanted to see the same objects in same places'. ${ }^{9}$ There are many people in Salem, added Lynda Hartigan, the James B. and Mary Lou Hawkes Chief Curator, who wish that the two museums had never merged: 'I have met any number of people who are now adults who said my mother used to drop me off on Saturday mornings and then pick me up at 5:00 p.m. They did this as children. It was hard for them to let go'.10

A closer read of these early critiques, raised at the time when the PEM's transformation had just begun in earnest, reveal a more complex set of concerns. Many locals, and some staff, worried that the new museum was turning away from its strengths and historical mission-and perhaps from Salem and New England too. 'The Peabody Essex, which is undergoing a $\$ 100$ million expansion,' reported Boston Globe's Kathy McCabe (1999), 'now bills itself as a museum of 'art, architecture, and culture,' with no reference to its seafaring legacy or its lofty status as a repository of early American historical artifacts'. One anonymous 'longtime museum member' complained to McCabe that 'beginnings are important, and from what l've seen unfold at that museum in recent years suggests to me that beginnings don't count for very much anymore there'. Another critic worried that the museum was turning its back on its areas of greatest strength, suggesting that 'they certainly have de-emphasized the maritime side. I don't know why. If they had asked me, I would have said, "Stick to the sea"... The Peabody Museum was America's great maritime museum.' He questioned whether the new focus on global art and culture would appeal to Salem's visitors: 'I don't think people coming to Salem are coming to see international art. They're coming to see the China Trade, the seaport, and learn more about the witch trials' (McCabe 1999).

Monroe argues that the PEM's transformation was a return to, rather than a departure from, its greatest strengths and institutional legacy. ${ }^{11}$ From his perspective, the PEM achieved its makeover by reconnecting to its institutional DNA and to the cultural armature of the city around it. Until the late nineteenth century, Salem and its maritime industry were world renowned. Therefore, the reasoning goes, global connections and concerns have always been part of the PEM's portfolio and also run deep in Salem's cultural structures. ${ }^{12}$ In order to build a strong and sustainable new PEM, Monroe and others believed they must reconnect the institution to its inherent cosmopolitan foundations, and to excavate and articulate in new ways what had always been a simultaneously global and regional story.

When Monroe arrived at the PEM, he said he wanted to create a new kind of art museum that went beyond the standard mission of collecting, preserving, interpreting, and acquiring. Instead, he explained, the new PEM would create artistic and cultural experiences, ideas, and information that transform people's lives. Museum staff designed a variety of exhibits as well as programming, special events, and educational efforts to spark these personal transformations which, subtly or dramatically, might happen immediately on site or cumulatively over time., 
Art, curators believe, has the capacity to bridge time, space, and cultural boundaries by helping people imagine themselves and their place in the world differently. It can therefore be a powerful tool for building cosmopolitan values and skills. Moreover, art is best understood, and has its greatest impact and meaning, if it is connected to the cultural world in which it is made. In many museums, that kind of contextualization is often relatively superficial or firmly aesthetic, e.g., piping in local music to create a multi-sensory experience. The PEM, under Monroe, tries to go further by crafting exhibits and programming that convey to visitors that while all societies create art, different cultures have different relationships between people and objects that shape their artistic practices and creations. ${ }^{13}$ Monroe's cosmopolitan vision for the PEM, therefore, hinges on several key principles: rooting objects in their unique cultural context so that they can be better understood; facilitating cross-cultural connection through the aesthetic appreciation of art; and inspiring visitors to explore artistically, intellectually and ethically.

To achieve this, Monroe drew on what he says is the museum's actual history (which differs markedly from the critiques discussed above). Up until the 1990s, the Peabody Museum, says Monroe, thought it was a maritime museum, and so did most of its visitors. But while the Museum does have an outstanding collection of maritime art, scrimshaw, ship models, and the like represent only eight percent of its holdings. The Museum's founders, Monroe believes, were much more interested in celebrating art from around the world than recording their everyday lives as sailors. They were also, effectively, collectors of contemporary art and culture. ${ }^{14}$ Using the museum's collections to connect to the global is simply returning to what many of the institution's founders originally intended, to showcase - literally, how global tastes and trends influenced what were ostensibly local objects. By reinterpreting objects through a global lens, the PEM adopted a cosmopolitan stance, embracing intrinsic aspects of its local cultural armature rather than disregarding them. Doing so, enhanced its cultural position and also repositioned the city around it.

\section{Enabling Cosmopolitan Roots to Flourish}

What does the PEM's vision of its mission and key values mean in practice? Many museums around the world that are struggling to connect art more meaningfully back to the cultural context in which it was created, The PEM's answer is to move from culture back to art. When Chief Curator Hartigan first arrived, she recalls a museum that was so deeply accustomed to classifying its objects as ethnographic materials, it was hard to get staff to talk about the collections as art. Objects in the storerooms, for example, were labeled 'artifacts' rather than 'art.' Even if the museum already had 32 other examples, curators often suggested acquiring a $33^{\text {rd }}$, with slightly different characteristics, if it had been collected by an important regional figure. Now, Hartigan said, staff are far more likely to make decisions about acquisitions based on aesthetic quality and cultural significance and to think strategically about how the PEM can use new acquisitions to take advantage of opportunities other institutions have missed. Curators are told to imagine how new purchases might also contribute to the goals of other departments. ${ }^{15}$

Similarly, the PEM no longer segregates its collection into separate galleries for paintings, furniture, decorative arts, and other genres. Visitors enter rooms filled with a variety of materials, arranged thematically rather than chronologically. In this way, Monroe says, the Museum eschews what he sees as false distinctions between high and low art. ${ }^{16}$ Historical works are placed alongside contemporary art rather than being arranged in a linear story line. If an object in one gallery sparks visitors' interest, staff encourage them to seek out related objects in different galleries. The PEM also avoids extensive labels. 'How many people really need to know the intimate history of Impressionism between 1870 and 1880?' Monroe asked. He dismisses traditional didactic techniques that, he believes, have never worked well because labels can capture the obvious or a very watered-down version of what is not obvious. 'They demonstrate,' he argues, 'that the person who wrote them actually got their MA and learned how to do art speak' and nothing more. ${ }^{17}$

In the same way that the Museum's staff want to blur the boundaries of time and space, they are also chipping away at the walls between curatorial departments. As Dan Finemore explained, 
One of the things about the PEM that I have always liked [is that] because it has such a long and winding history... it doesn't divide things up in standard museum fashion. Our curatorial departments are hugely overlapping, they're not really departments any more but sort of areas of curatorial expertise. It's much better when we work together not in silos. I don't think we're unique, but it's easier here than in other museums where the silo structure is stronger. ${ }^{18}$

Many museums, according to Monroe, work to engage feeling and emotion, but the PEM's staff view emotion and thought and rationality and creativity as inextricably linked. They are mutually constituitive rather than in conflict. Therefore, he explains,

We are not here to teach you Art History 101. We want to create an experience that generates emotions. We even talk about feelings in our advertisements: 'No museum has made you feel this way'. ${ }^{19}$ People might not get it [the ideas shaping a particularly gallery or exhibition] explicitly, but they feel it. We offer rather than impose. It's a proscription for the journey not a conclusion.'

Staff hope that as a result of having his or her emotions affected, the visitor will grasp that there are universal human experiences that enable cosmopolitan cross-cultural connection. 'We want,' said Hartigan, 'to show the commonality across fields, to create experiences that suggest the art of connectivity rather than separateness' ${ }^{20}$ It is not easy, she says, because art history is very nationalistic; historically, Western viewers have not been dissuaded from their common view that all non-Western art is exotically alien, decorative, and essentially similar regardless of its particular cultural origins. Therefore, she says, curators had to fight to get the public to understand that Chinese art was not the same as Korean or Japanese art. Even now they are often hard-pressed to give up this hard won territory.

As it is presently told in its galleries, the PEM's story is inherently global. Even if visitors do not realize that many objects were made for the export market, when they walk from gallery to gallery, they encounter India, China, and the rest of the world in quick succession. By highlighting the relationship between particular objects in an exhibition and other pieces in the collection, by putting things near each other, or by directing visitors with maps and signage, the PEM calls attention to cross-cultural connections and translations. In the Chinese export porcelain gallery, for example, curators exhibited a sculpture of a woman wearing what could have been interpreted as a traditional Chinese dress with a mandarin collar; a closer look reveals that it is a typical western dress as seen by a Chinese artist. 'There is a lot of conversation out there about Chinese artists today making art for the western market', said Hartigan,

but one could argue that what is happening today is really a timely version of what they did in the past. Asian export art is at the root of all things made in China from the tschoke [curios] to the treasure.

\section{What Happens to the Local and at What Cost?}

The PEM took advantage of its unique local legacy and the cultural armature of its city to reinvent itself as a globally relevant museum. But where does the local fit into this reinvention? Although it might seem like a contradiction, Monroe's embrace of the global was motivated, in part, by a desire to attract a wider local audience. The Wall Street Journal's Judith Dobrzynski (2013) explains this shift as a counter-intuitive but successful business strategy:

Salem is a historic town, and the museum used to depend on attracting $65 \%$ of its audience from tourists and $35 \%$ from the local population. By the time Mr. Monroe arrived, however, historic sites were losing their appeal to Americans. The Peabody Essex decided to stress art and culture, instead of history, and to reverse its visitor targets: $35 \%$ should be tourists and $65 \%$ should come from the area. That gives you a dynamic relationship with the community and the capability to develop a support base. To draw more local visitors, the museum had to turn them into repeat visitors. So, over the years, its collections have evolved to include more art, its programs to offer more changing exhibitions, 
and its buildings expanded twice to provide more space for galleries, programs, a bigger gift shop, a glass-enclosed atrium where visitors may rest their eyes between gallery visits, and so on.

In other words, in an effort to attract a loyal, returning local visitor base, the museum decided to go beyond the local, telling new and wider-ranging stories with the same objects, in essence re-scaling itself within wider cultural maps.

So far, the PEM has achieved its goals of sustainability and an enhanced profile by highlighting the global roots of its collections. Curators dusted off objects that had had been relegated to the storerooms for decades, using them to tell more complex narratives that take into account the context in which they were created and the paths they traveled to get to the PEM. 'We are not interpreting the collection from a New England perspective,' Monroe explains, 'The collection is, in some ways, deeply local, but its reach and influence extend far beyond this space. Our materials could be plunked down anywhere and they would be meaningful'. ${ }^{21}$ In other words, in the PEM's parent institutions, international objects were deemed important and worthy of display because of their local New England origins or contexts, e.g., as illustrations of the Old China Trade, historic events, or distinctively regional aesthetic styles or techniques. Now a local object is important and worthy of display because of its cultural importance and quality; it has to measure up to international standards of excellence and significance, however defined (a crucial point and a source of contestation).

This shift in what gets displayed and how it is contextualized requires negotiation, and not all visitors and stakeholders are comfortable with the outcomes. Some, including several PEM curators, point out that the museum has a number of objects possessing what was long considered significant local historical value that are no longer on display. An eighteenth-century plough depicted in Concord, Massachusett's famous Minute Man statue commemorating the American Revolution (installed for the 1876 centennial) is now in storage because decision makers feel it 'lacks artistic value'. Similarly, the PEM has extensive social history, whaling, and medical collections that, in the critical words of one curator, 'are just collecting dust'. ${ }^{22}$ Others argue that deciding that the history of impressionism or labels with extensive art historical explanations are not for everyone, as Monroe has done, replicates the very elitism it seeks to ameliorate.

But paradoxically, the PEM's commitment to present only works of outstanding artistic quality and cultural resonance elevates the status of the local objects that are on display. Rather than serving as illustrations of local history and being considered important simply because they are regionally significant, these objects now speak to the significance and quality of New England art and culture on the global stage. As we write, the PEM's Special Exhibition Gallery is hosting a major exhibition of works by eighteenth-century cabinetmaker Nathaniel Gould, whose obscurity, according to exhibit reviewer Barrymore Laurence Sherer (2015), 'was transformed into renown as one of the most important eighteenth-century American cabinetmakers' after many outstanding pieces of furniture were recently re-attributed to him and his workshop.

The Gould exhibit, titled 'In Plain Sight', reflects the PEM's commitment to connect local objects and artistic production to global processes. It locates the craft person's masterworks into the global cultural context in which they were produced and consumed by displaying them alongside 'a selection of complementary period objects... including portraits of Gould clients by John Singleton Copley and other artists, and a copy of Thomas Chippendale's influential design book', as 'Gould was a primary force in introducing Chippendale's style to Salem' (Sherer 2015). In addition, the exhibition clearly links history to contemporary artisanal practice. 'A video [showing] master cabinetmaker Philip C. Lowe, director of the Furniture Institute of Massachusetts, hand-carving various furniture elements using Gould's time-honored methods' emphasizes the technical mastery Gould and his workshop achieved and which craftspeople still employ (Sherer 2015). Also characteristic of the PEM, Sherer (2015) notes, is the emphasis on quality over quantity, aesthetic resonance over encyclopedic illustration: 'Gould's discerning eye for [fine wood] is apparent in every mahogany piece on display. Hence the case pieces, tables, chairs and related objects arranged in a single spacious gallery constitute an exhibition overwhelming not in size but in beauty.'

With 'In Plain Sight,' the PEM locates Salem's artistic heritage in a cosmopolitan, international sphere, alongside the likes of famous Chippendale works. Along the way to the 
gallery where it is on display, visitors pass Chinese export art masterworks and innovative contemporary artworks such as those in 'Branching Out: Trees as Art,' which 'explores the often surprising ways in which contemporary artists use trees as an inspiration as well as a medium for their art.' ${ }^{23}$ Gould's work, the PEM implicitly suggests, would be important, beautiful, and valuable whether it had been made nearby or far afield. His creations are displayed as art objects worthy of examination for their purported universal artistic and cultural value as well as their historical links.

This approach is emblematic of the ways in which the PEM, while turning its point of view outward, works to offer local visitors a new way to look inward. By doing so, it encourages them to re-contextualize themselves and their communities within the broader world. A wall plaque greeting visitors drives home that what happened in Salem or Massachusetts was always inextricably connected to and influenced by cultures worldwide. It reminds visitors that:

members of the East India Marine Society ...brought the art and cultural objects they saw and admired as they circled the globe in search of opportunity. These adventurers and entrepreneurs were among the first Americans to recognize the remarkable diversity of people in the world and the extraordinary objects of their creativity. Today, this room...is a reminder of the legacy left to us by those whose portraits line these walls (transcribed in Boswell 2008: 48.)

The plaque does not merely commemorate or celebrate local heritage, as it may have in the PEM's parent institutions. Rather, it encourages readers to take the PEM's well-traveled founders as role models for exploring and appreciating other cultures: "let this be the launching point of your journey into world art!'

For local visitors, the plaque, and the PEM's implicit presentation of the local and global as mutually constitutive and reinforcing, has a special resonance. Salem, as re-imagined in the PEM, was once a centre of global connection and cosmopolitanism, an international player in cultural exchange. It was not merely a provincial hub but a site where ideas and art cross-fertilized and blossomed, from which New Englanders embarked on journeys around the world, and to which they brought home the works of artists and craftspeople who had learned their trade and carried it out far across the sea from Massachusetts. Paradoxically, though the Peabody Museum and Essex Institute focused far more narrowly on Salem's heritage, the city's cultural significance, from their point of view, was far less inclusive than the global legacy claimed by the PEM's current vision. The new museum encourages locals in particular to follow the example of their forebears by actively embracing their place in the wider world and the rights and responsibilities of global citizenship.

The PEM will not, said Monroe, do exhibitions on global problems, such as trafficking, climate change, or poverty, as he sees this as outside the PEM's intended purview. But he does want the museum to broaden visitors' minds and open them to cross-cultural exchange. In essence, Monroe's goal is to develop cosmopolitan values and skills without explicitly taking a stand on cosmopolitics:

While we have a lot of trouble remembering it, every group creates its own art and culture, we all share basic desires that tie us together as human beings. What I want to do is brain flexing, to encourage people to be more exploratory, to take accepted ideas and test them, to learn to think creatively and outside the box and to accept that there are lots of values around the world other than one's own.

The PEM, however, consciously cultivates a special relationship with local visitors; characteristically, admission is always free for Salem residents. As the Wall Street Journal (2013) points out, forging relationships with residents from the region remains as central to Monroe's strategy as the turn to international art and culture. But while the PEM's new take on Salem's history and its reinvention into an international art destination has rescaled Salem on the global cultural map, it remains to be seen whether it will also enhance the city's economic fortunes. 


\section{Conclusion}

In 1993, the Peabody Museum and the Essex Institute were poised to close. Despite their long histories and important collections, they were operating at the far frontier of the regional cultural map. In the ensuing years, the new PEM rewrote that cartography. By telling new global stories about very local objects, and by showcasing its global institutional roots, it dramatically transformed visitors' experiences. It broadened and diversified the possible messages they might take away from their visits and sought to connect them to other times and places. Exposing visitors to the linkages between objects, and their geographically and socially disparate trajectories, drives home the ways in which local objects and events are deeply embedded in and affected by broader, though starkly unequal, cultural and economic networks. Excavating pieces of Salem's cultural armature enabled the PEM to display cosmopolitan ideas and to cultivate cosmopolitan skills while rescaling itself and its city in the process.

Richard Florida's (2014) now famous treatise on the creative class, and the role the cultural institutions they create play in urban redevelopment, has spurred much debate. $\mathrm{He}$ argues that this new group, with its penchant for innovation and creative ideas, will replace manufacturing titans as the key economic drivers in our post-industrial economy. Creativity and culture, the logic goes, will bring back dying industrial cities like Salem and Detroit. But while the PEM has clearly rescaled Salem, and put it on the global cultural cultural map, has it also re-scaled the city economically? Do these repositioning processes always go hand and hand?

A brief look suggests that the jury is still out. Tourism is still the city's primary economic catalyst. In addition to the PEM, visitors flock to the 'witchy' city each year to visit sites related to the Salem Witch Trials and author Nathaniel Hawthorne. Salem State University is also an important anchor. As the region recovers from the 2008 economic recession, real estate values in Salem appear to be making a comeback (Gehrman 2014). But, in 2010, unemployment in Salem was $8.3 \%$, compared to the $7.4 \%$ state average. And while the average income for White residents $(\$ 39,055)$ is higher than the national average $(\$ 31,133)$, the average income for African Americans $(\$ 24,020$ compared to $\$ 25,062)$ and Latinos $(19,699$ compared to 21,505$)$ was lower. (http://www.usacityfacts.com/ma/essex/salem/economy/). Cultural rescaling does not always proceed in tandem with economic rescaling, just as repositioning an institution within the global cultural hierarchy does not always transform the fortunes of the city where it is located.

Received $2^{\text {nd }}$ March 2015

Finally accepted $29^{\text {th }}$ September 2015

\section{Notes}

1 2015. 'About PEM: Mission \& Vision Statement', PEM.org. Retrieved 1 March 2015 (http:// www.pem.org/about/mission_vision).

2 The interviews lasted between 1-3 hours. They were recorded and transcribed. Dan Monroe read and commented on the book chapter that includes portions of the findings presented here.

3 Dan Monroe, Rose-Marie and Eijk van Otterloo Director and CEO of the Peabody Essex Museum, interview by author Levitt, digital recording, 2011, Salem, MA.

4 2015. "About PEM: Mission \& Vision Statement." PEM.org. Retrieved 1 March 2015 (http:// www.pem.org/about/mission_vision).

5 Including the campaign by Boston's Museum of Fine Arts to build its new Art of the Americas Wing which opened in 2010.

6 Frayler, John. 2008. "Privateeers in the American Revolution." The American Revolution: Lighting Freedom's Flame. Retrieved 1 March 2015 (http://www.nps.gov/revwar/about_the revolution/privateers.html).2011. "Salem's International Trade." Salem Maritime National Historic Site. Retrieved 1 March 2015 (http://www.nps.gov/sama/learn/historyculture/trade. $\underline{\mathrm{htm}})$. 
7 Monroe, interview, 2011.

8 Monroe, interview, 2011.

9 Dan Finemore, Russell W. Knight Curator of Maritime Art and History, Peabody Essex Museum, interview by author Levitt, digital recording, 2011, Salem, MA.

10 Louise Hartigan, James B. and Mary Lou Hawkes Chief Curator, Peabody Essex Museum, interview by author Levitt, digital recording, 2011, Salem, MA.

11 Monroe, interview, 2011.

12 Monroe, interview, 2011.

13 Monroe, interview, 2011.

14 Monroe, interview, 2011.

15 Hartigan, interview, 2011.

16 Monroe, interview, 2011.

17 Monroe, interview, 2011.

18 Finemore, interview, 2011.

19 Monroe, interview, 2011.

20 Hartigan, interview, 2011.

21 Monroe, interview, 2011.

22 Finemore, interview, 2011.

23 2014. "Exhibits: Branching Out: Trees as Art." PEM.org. Retrieved 1 March 2015 http:// www.pem.org/exhibitions/175-branching_out trees as art.

\section{References}

Anderson, E. (2010) The Cosmopolitan Canopy: Race and Civility in Everyday Life, New York: W.W. Norton \& Co.

Beck, U. and Grande, E. (2007) Cosmopolitan Europe, Cambridge, UK: Polity Press.

Boswell, A (2009) 'Re-enactment and the Museum Case: Reading the Oceanic and Native American Displays in the Peabody Essex Museum', Journal of New Zealand Literature 27: 48-69.

Çaglar, A. and Glick-Schiller, N. (2011) 'Introduction: Migrants and Cities', in Glick-Schiller, N. and Çaglar, A. (eds) Locating Migration: Rescaling Cities and Migrants 1-22, Cornell: Cornell University Press.

Calhoun, C (2008) 'Cosmopolitanism in the modern social imaginary', Daedalus (Summer): $105-114$.

Cook, G. (2012) 'New Hire Is One More Sign of The Peabody Essex's Amazing Rise', WBUR, http://www.wbur.org/2012/12/12/peabody-essex-future, accessed 1 March 2015. 
(2008) 'Peabody rising', Boston Phoenix, July 23 http://thephoenix.com/Boston/Arts/65306Peabody-rising/, accessed 1 March 2015

Daugbjerg, M. (2009) 'Pacifying War Heritage: Patterns of Cosmopolitan Nationalism at a Danish Battlefield Site', International Journal of Heritage Studies 15 (5) 431 - 46.

(2013) Borders of Belonging: Experiencing History, War, and Nation at a Danish Historical Site, New York and Oxford: Berghahn Books.

Dobrzynski, J (2013) 'A New Way Forward: Cultural Conversation with Dan L. Monroe, Peabody Essex Museum', Wall Street Journal, January 28.

Edgers, G. (2011) 'Peabody Essex vaults into top tier by raising $\$ 550 m$ ’, Boston Globe, November 6, A1.

Feldman, J. (2008) Above the Death Pits, Beneath the Flag: Youth Voyages to Poland and the Performance of Israeli National Identity, Oxford: Berghahn Books.

Florida, Richard. 2014. The Rise of the Creative Class-Revisited: Revised and Expanded. New York:Basic Books.

Gehrman, E. (2014) 'Greater Boston's Top Spots to Live 2014: 13 communities where the real estate market is sizzling', Boston Globe https://www.bostonglobe.com/ magazine/2014/05/09/greater-boston-top-spots-live/KyDmP2xQfEaRcOxisr0cGM/ story.html 11 May.

Gilroy, P. (2005) Postcolonial Melancholia, New York: Columbia University Press.

Glick-Schiller, N.; Çaglar, A.; and T. C. Guldbrandsen (2006) 'Beyond the ethnic lens: Locality, globality, and born-again incorporation', American Ethnologist 33 (4) 612-33.

Hannerz, U. (1990) 'Cosmopolitans and Locals in World Culture', Theory, Culture \& Society 7(2): 237-251.

Hart, G. (2006) 'Denaturalizing Dispossession: Critical Ethnography in the Age of Resurgent Imperialism', Antipode 38 (5) 977-1004.

International Organization of Migration. 2015. World Migration Report 2015. (Electronic document https://www.iom.int/world-migration-report-2015>, accessed 15 March $\underline{2016)}$

Jaworsky, N.; Wendy Cadge.; Levitt, P.; and S. Curran (2012) 'Rethinking Immigrant Context of Reception: The Cultural Armature of Cities', Nordic Journal of Migration and Ethnicity 2 (1) 78-88.

Kymlicka, W. and Norman, W. (eds) (2000) Citizenship in Diverse Societies, London and New York: Oxford University Press.

Latour, B. (2004) 'Whose Cosmos, Which Cosmopolitics? Comments on the Peace Terms of Ulrich Beck', Common Knowledge 10 (3) 450-62.

Levitt, P. (2015) Artifacts and Allegiances: How Museums Put the Nation and the World on Display, Berkeley and Los Angeles: University of California Press.

Levitt, P. and Nyiri, P. (2014) 'Books, Bodies, and Bronzes: Comparing Sites of Global Citizenship Creation', Ethnic and Racial Studies 37 (12): 2149-57.

Levy, D. and Sznaider, N. (2006) The Holocaust and Memory in the Global Age, 
Philadelphia: Temple University Press.

Lindgren, J. M. (1995) "That Every Mariner May Possess the History of the World": A Cabinet for the East India Marine Society of Salem', The New England Quarterly 68 (2) 179-205.

Macdonald, S. (2013) Memorylands: Heritage and Identity in Europe Today, London and New York: Routledge.

McCabe, K. (2005) 'Museum Donors Set Records', Boston Globe, April 24.

McCabe, K. (1999) 'Peabody Essex Sets Sail: Salem Museum Shifting Focus from Maritime to International', Boston Globe, October 10.

Murphy, K. D. (2003) 'PEM: Ship-Shape', Art New England 24 (6) 11, 63.

Nowicka, M. and Rovisco, M. (eds) (2009) Cosmopolitanism in Practice, Farnham, England: Ashgate.

Pochoda, E. and Gustafson, E. H. (2014) 'Talking past and present', Antiques, January 9, http://www.themagazineantiques.com/articles/talking-past-and-present-at-thepeabody-essex-museum/, accessed 1 March 2015.

Saito, H. (2011) 'An Actor-Network Theory of Cosmopolitanism', Sociological Theory, 29 (2) 124-49.

Sherer, B. L. (2015) 'Bewitching Wood in Salem (Review: 'In Plain Sight: Discovering the Furniture of Nathaniel Gould')', Wall Street Journal, January 12.

United Nations Information Service. 2014. 232 Million International Migrants

Living Abroad Worldwide-New UN Global Migration Statistics Reveal. (Electronic document, http://www.unis.unvienna.org/unis/en/pressrels/2013/unisinf488.html accessed 09 September 2015)

United Nations High Commissioner for Refugees. 2015. UNHCR warns of dangerous

new era in worldwide displacement as report shows almost 60 million people forced to flee their homes. (Electronic document, <http://www.unhcr.org/cgi-bin/texis/vtx/ search?page $=$ search\&docid $=55813$ f0e6\&query $=60 \% 20$ million $\% 20$ refugees $>$, accessed 15 March 2016)

US City Facts (nd), Salem, Mass: Income and Economy. http://www.usacityfacts.com/mal essex/salem/economyl, accessed March 13, 2016, taken from 2010 Census.

*Peggy Levitt is Chair and Professor of Sociology at Wellesley College and a Senior Research Fellow at Harvard University where she co-directs the Transnational Studies Initiative. Her new book, Artifacts and Allegiances: How Museums Put the Nation and the World on Display was published by the University of California Press in Summer 2015.

** Katherine Cali graduated from Wellesley College with a degree in history and sociology in 2013.

Corresponding Author: Peggy Levitt,

Department of Sociology,

Wellesley College,

Wellesley, 
Mass 02481.

plevitt@wellesley.edu 